\title{
4 \\ Patterned Responses to Organizing: Case Studies of the Union-Busting Convention
}

Richard W. Hurd and Joseph B. Uehlein

In June 1993, the Industrial Union Department (IUD) of the AFL-CIO initiated a project to gather cases from affiliated unions that would highlight aspects of the National Labor Relations Board process deserving attention from those shaping labor law reform proposals. Based on the cases submitted, we conclude that in its current form the National Labor Relations Act serves to impede union organizing. Particularly problematic are NLRB policies that allow employers to wage no-holds-barred antiunion campaigns. Even where there are legal restrictions on specific actions, the penalties for violations are so meager that they serve no deterrent effect. The cases described below cover many industries, all parts of the country, large units and small, and collectively suggest that union busting has become the convention among U.S. employers.

\section{Overview of the IUD Case Studies Project}

The request for case studies that the IUD circulated was relatively broad but focused primarily on union organizing. By October 1, 1993, we had received 213 case studies from twenty-one national unions. Of these, 167 reported on organizing campaigns; included were campaigns in thirty-six states, the District of Columbia, and Puerto Rico. Most were submitted as brief summaries of one to four pages. This chapter highlights aspects of nineteen representative cases for which additional information was gathered through database searches and requests from the organizing and legal departments of the unions involved.

The picture that emerges from a review of the cases is clear. Under the current legal structure, companies faced with an organizing drive are free to 
conduct intense antiunion campaigns. Even those companies that have good relations with unions at other facilities often bitterly oppose union organizing. Union avoidance routinely involves the use of a management lawyer or consultant who is expert at defeating worker efforts to organize. Although many antiunion campaigns are run within the limits of the law, many others openly violate NLRB policies. The most common violation is discrimination against union activists in job assignments, discipline, and discharge. If the union manages to win the election, the employer often appeals certification to delay bargaining, in some cases for years. Even if the union is ultimately certified as bargaining agent, management may engage in hard bargaining as part of a long-term strategy to decertify the union.

The remainder of this chapter is devoted almost exclusively to summaries of the cases themselves. We believe that they offer compelling testimony to the need for labor law reform. In each topical section below, we offer several brief examples plus one case summary to give the reader a taste of the intensity of employer hostility toward workers who attempt to organize. ${ }^{1}$

\section{Union-Avoidance Routine}

A typical scenario has evolved for the employer's response to an organizing campaign. Consider, for example, the case of Aero Metal Forms in Wichita, Kansas. When twelve of the fifteen employees approached the International Association of Machinists (IAM) ${ }^{2}$ about organizing a union, the company hired an attorney to design an antiunion campaign. Supervisors were trained to identify and combat union supporters, and captive audience meetings were held. Workers were warned that the union would take them out on strike and that they could be replaced; they also were threatened with plant closure. The two most vocal union supporters were fired. The April 22, 1991, election resulted in a 6-6 tie with three challenged ballots. By the time the NLRB reached a final decision and declared the union a 7-6 winner on April 5, 1993, only one union supporter still worked for Aero Metal.

Even in the face of overwhelming evidence that their employees want union representation, some companies will go to great lengths to avoid recognition and bargaining. On May 27, 1992, Local 26 of the United Food and Commercial Workers (UFCW) requested recognition from Home Style Foods in Hamtramck, Michigan, based on thirty-four signed cards from the thirtyfive employees. The company denied the request, hired a consultant, and implemented a textbook union-resistance campaign: captive audience meet-

1. The examples and case summaries are based on material submitted by the unions involved. A list of contact persons and supporting citations will be provided by the authors on request.

2. Standard union abbreviations are used throughout, as indexed in Gifford 1992. 
ings, a suggestion box, letters to employees at home, warnings about union strikes and permanent replacements, advance payment of bonuses, a new arbitration system to resolve worker complaints, discipline and dismissal for vocal union advocates, and even a promise from the owner to "fight this to the very end and that could take years." In spite of the campaign, the UFCW won the July 21, 1992, election and has prevailed on every subsequent NLRB decision. Nonetheless, there was still no contract in October 1993, seventeen months after 97 percent of the employees expressed their desire for union representation.

Although most management campaigns attack unionization on many fronts, some are more narrowly focused. In February 1993, the Amalgamated Clothing and Textile Workers Union (ACTWU) collected authorization cards from a majority of workers in a two-plant unit in Louisiana-Crowley Manufacturing and Jennings Manufacturing. The employer adopted a single theme: Vote union and you will lose your job. This message was repeated via captive audience meetings, one-on-one discussions, written communications, bulletin boards, lawn signs, and radio ads. Walls of the factories were covered with newspaper articles, blown up to five feet by three feet, about plant closings. A twelve-foot-by-three-foot banner proclaimed, "Wear the union labelUNEMPLOYED." Sets of two identical pairs of pants were hung around the factories, and supervisors explained that the only difference was that one pair was made in Crowley or Jennings for five dollars per hour and the other was made in Mexico for three dollars per day. The NLRB refused to issue a complaint on unfair labor practice charges, in essence condoning the threats. The union lost the election $275-222$.

\section{CWA v. HarperCollins, San Francisco}

HarperCollins in San Francisco, owned by Rupert Murdoch, publishes psychology, feminist, and religious books. Half of the 150 highly educated employees are eligible for union membership, 80 percent of them women. Months of effort on employee-management task forces produced very little change, prompting a group of workers to contact the Cómmunications Workers of America (CWA). On December 18, 1992, CWA filed an NLRB petition for a unit of eighty-three employees (sixty-two signed the petition).

HarperCollins sought to exclude twenty employees from the unit (CWA agreed to four). The NLRB held eight days of hearings in January and February 1993 . The hearings were prolonged by management lawyers, who, for example, questioned a receptionist for three hours about her duties. The NLRB ultimately ruled with the union and included all sixteen contested employees in the unit. The decision was not issued until May 28, however, and the election was scheduled for June 18. 
During the intervening months the company implemented a standard union-resistance campaign. Letters were sent to all employees at home, one from Vice President Clayton Carlson opposing "the insertion of an outside factor like CWA"; another was signed by all the managers, who argued that unionization "would not serve to promote cooperation and solidarity." CEO George Craig flew in from New York and held captive audience meetings. He declared, "This is war," and labeled as "disloyal" all employees involved with the CWA. He then promised to negotiate with an in-house association if employees dropped the union.

The company also made a series of personnel changes. Two workers were promoted out of the unit, and four were laid off. Five of these six were on the organizing committee, and the other was a vocal union supporter. Subsequently, eleven new employees were hired who voted in the election.

The aggressive resistance campaign succeeded. The CWA lost the June 18 election 31-36 with four ballots challenged. On August 31, the NLRB issued a complaint against HarperCollins on twelve violations charged by the union, including the four terminations. A hearing on the charges was scheduled for December 1993.

\section{Legal Delays}

Legal delays are a major barrier to organizing. As described above, management lawyers frequently challenge unit determinations to buy time for a union-resistance campaign. In many situations, though, legal delay is more than a temporary stalling device. In 1964, the Service Employees' International Union (SEIU) won the right to represent maintenance employees at Long Island College Hospital in New York City. The hospital pursued a tenyear legal challenge to the appropriateness of the unit that went all the way to the Supreme Court. The parties then began bargaining, but the passage of the 1974 health-care amendments to the NLRA prompted a second round of legal challenges by the hospital, which lasted five years. The SEIU won a second election in January 1979 and was certified in August 1980. The employer refused to bargain, prompting a series of ULPs filed by the union and nine more years of hearings and appeals. When the NLRB issued rules establishing appropriate units for the health-care industry in 1989, the hospital again challenged the unit. In April 1993, the NLRB upheld an administrative law judge's (ALJ) decision and issued a bargaining order. As of October 1993, there was still no contract, twenty-nine years after the workers first voted for representation.

A number of unions report that employers now are using the threat of legal delays to defeat unions. In an ACTWU organizing campaign at BMP Ameri- 
can in Medina, New York, the company successfully undermined support for the union with the aid of a June 8,1993 , memo to employees:

This outside union has filed two sets of charges against the company. ... Unfortunately, we have started on the road of a very, very long process. Our attorneys have advised us that generally the steps involve: an investigation, a possible trial, . . a possible appeal to an NLRB panel, ... and even a possible appeal to a Federal Appellate Court. ... Many cases have lasted 5,6 , or 7 years until they become final.

A similar approach was used by Crown Cork and Seal while opposing organizing by the United Steel Workers of America (USWA) at its Puerto Rico facility in 1990-91. The aggressive resistance is particularly noteworthy because the USWA has a good bargaining relationship with this employer in thirty-six plants in the United States and Canada. But this did not stop the company from making threats explicitly tied to legal delays in a lengthy December 11, 1991, memo sent to each worker at home (translated from Spanish):

5. The company has prepared ULP charges for the NLRB. ... The judge can issue a decision between two and twelve months. Either party can appeal. ... The board can reasonably issue a decision between two months and two years. Either party can appeal. ... It can reasonably take between six months and eighteen months for the court of appeals to issue a decision. Either party can appeal. ...

6. If there is an election and the Steelworkers win, the company would challenge the results. ... This means that the company would nullify the need to negotiate with the USWA.

7. If the USWA does not like the company's refusal to negotiate, it would have to file ULP charges-the company would appeal to the NLRB and the court of appeals. This process could take two years or more.

\section{AFSCME v. Fountain Valley Regional Hospital, Fountain Valley, California}

In May 1986, an affiliate of the American Federation of State, County, and Municipal Employees (AFSCME) was contacted by registered nurses and other professional employees at Fountain Valley Regional Hospital. After collecting 520 authorization cards from a unit of 650 (80 percent), AFSCME filed for an election in November and the delays began. The hospital challenged the unit and presented lengthy testimony on a wide variety of technical and confidential employees. The hearings stretched over eight days in December 1986 and January 1987. The NLRB issued its decision on the unit on April 1, 1987, and scheduled the election for April 30 and May 1. 
Management used the five-and-one-half-month delay to implement an antiunion campaign replete with the standard threats, promises, and captive audience meetings. The campaign was coordinated by the West Coast Industrial Relations Association (WCIRA), a consulting firm known for its "Maintaining Your Union Free Status" seminars. Based on papers filed by WCIRA with the U.S. Department of Labor, Fountain Valley paid more than $\$ 365,000$ for union-avoidance assistance during the first year.

The election results were 278 for AFSCME and 274 for no union and 28 challenged ballots ( 24 by the employer, 4 by the union). The regional office of the NLRB considered the challenges and issued a decision on November 16, 1987 . Both sides requested a review by the NLRB, which concurred with the regional office but not until October 1988. The challenged ballots were finally opened, and the union won 285-279. Fountain Valley refused to accept the results, appealed the decision, and refused to bargain, claiming that the union did not represent a majority of employees.

Throughout the process of determining the election outcome, the hospital continued its antiunion campaign, prompting numerous ULP charges. A series of decisions from the NLRB were ignored, until June 12, 1991, when the U.S. Ninth Circuit Court of Appeals ordered the hospital to bargain. Over the next twenty months bargaining sessions were held once per month and progress was painfully slow. Finally, on April 12, 1993, agreement was reached when the union resigned itself to accepting the status quo on most issues. Unbeknownst to AFSCME, a decertification petition had been filed two days earlier. Union members ratified the contract on April 16, but management refused to sign it. In the meantime, ULPs continued to pile up, and management openly violated an NLRB-ordered posting while it adorned hospital bulletin boards. There was still no signed agreement as of October 1993, six and one-half years after workers voted to be represented by AFSCME.

\section{Blatant Labor Law Violations}

Some employers are not content to work within the friendly confines of NLRB regulations. Instead, they openly violate the law, most often by discriminating against the leaders of union organizing drives. Nearly half the cases submitted to the IUD for this project included specific details of workers being disciplined, laid off, or fired for union activity. In most of them, the NLRB eventually ruled against the employer-but long after the organizing campaign had been halted by worker fear.

Consider ACTWU's organizing campaign at Surgical Appliance, Inc., in Cincinnati. Nearly half the 120 employees were visited in their homes over 
two days in early February 1993. Approximately 70 percent of those visited signed union authorization cards. Eight workers passed out organizing leaflets at the plant gate the next morning. An hour later all eight either were laid off or had their hours reduced. This scenario was repeated over the next few days until twenty-six union supporters were laid off. The organizing campaign had been stopped cold.

Six months later, Surgical Appliances and ACTWU reached a settlement with the NLRB - $\$ 70,000$ in back pay and a management agreement to cease and desist from interfering with union activity through threats, surveillance, unlawful restriction of the distribution of literature, interrogation, and discrimination. ACTWU won the NLRB case, but Surgical Appliance avoided unionization by breaking the law quickly and severely, scaring the workers into retreat.

Sheridan Manor Nursing Home in Buffalo, New York, responded similarly when faced with an organizing campaign by the CWA in late 1992. The push for unionization had originated among licensed practical nurses (LPNs), so Sheridan fired sixteen of its twenty-one LPNs on January 19, 1993, with no explanation. An election was held on August 5, but the ballots were impounded because of a company appeal of the unit determination. Subsequently, the LPNs were reinstated (without back pay) pending an NLRB hearing on the dismissals scheduled for October.

A case involving the United Mine Workers of America (UMWA) demonstrates that blatant violations of the law can be combined with lengthy legal appeals. In December 1988, the UMW A was contacted by employees of Power, Inc., an Osceola Mills, Pennsylvania, surface mining operation owned by Ryan International of Great Britain. An election petition was filed on January 6, 1989 (forty-eight of seventy-four workers in the unit had signed cards). On March 10, thirteen days before the election, the company laid off thirteen workers, all of them union activists, including the leaders of the organizing campaign. The vote at the March 23 election "was twenty-seven yes, thirty no, and ballots cast by the thirteen laid-off workers were challenged by the employer.

As the case worked its way through the NLRB process over the next four years, the company committed numerous ULPs, including laying off twelve additional union supporters. As new ULPs were filed, they were appended to the previous case. All of this delayed decisions on the challenged ballots and the prior charges. The ALJ's initial decision was not issued until May 6, 1992. The company, found guilty of most of the ULP charges, appealed. The NLRB issued its decision on May 28, 1993, upholding the ALJ decision on all substantive points. The thirteen challenged ballots finally were opened on June 22, and, as expected, all were for the union; the final vote stood at forty yes, thirty no. Power, Inc., appealed the decision to the District Court. 


\section{ILGWU v. Domsey Trading Corporation, Brooklyn, New York}

Domsey buys and exports used clothing, and its employees are mostly Haitian and Latin American immigrants. On December 1, 1989, a representative of the International Ladies' Garment Workers' Union (ILGWU) arrived at Domsey to request recognition. Seventy-six percent of the employees had signed cards in a unit of 243. A key union supporter with twentyseven years' seniority informed the owner's son that the union was there to see him. Fifteen minutes later, the union supporter was fired. That afternoon, the employer's attorney told the union's attorney that he was not worried, because even if the employer had to reinstate the discharged worker, the back-pay liability would not amount to much. By late January, Domsey fired two more pro-union workers. On January 30, 90 percent of the employees walked out because of the illegal firings.

During the strike, management representatives subjected the striking workers, most of whom were Haitian, and union organizers to outrageous harassment. The owner's son placed a "voodoo table" covered with a black tablecloth in front of picketing workers, placed candles and bananas on the table, and called to the workers, "This is for you monkeys to eat." He and his cohorts called women picketers "whores" and shouted explicit obscenities at them. They called the picketers "lazy" and "stupid niggers," and they told them that they were being sprayed with water to wash off their smells.

On August 10,1990, the 132 remaining strikers unconditionally requested to return to work. Domsey refused to rehire some of them, and those who were reinstated suffered severe abuse, including physical attacks and verbal harassment. A particularly repugnant management employee, later compared by an ALJ to Attila the Hun, physically attacked one union supporter and injured her seriously enough that she had to be hospitalized; he also screamed obscenities in the faces of others. Some union supporters quit in fear and disgust. Others were fired.

Over the next three years the NLRB took a consistent stance in opposition to Domsey's blatant disregard for the law. ALJ and NLRB decisions found the employer guilty of multiple ULPs. A court injunction ordered a halt to Domsey's discriminatory treatment of union supporters, and when the company ignored the injunction, the NLRB secured a contempt of court citation.

An election was eventually held on March 27, 1992, more than two years after the petition was filed. By this time only a third of the original union supporters still worked at Domsey, and the union lost 170-120. Although the NLRB overturned the election results, the company continued to avoid compliance with the law by appealing every decision. As of October 1993, the case was still before the U.S. Court of Appeals. 


\section{Weaknesses of NLRB Protections and Penalties}

Even when the NLRB concludes that management has violated the law, its options for achieving compliance are limited. As noted above, it is standard practice for management lawyers to raise objections in order to delay an election, and in the event that the union wins, to challenge the results and delay certification. Such was the case in 1989 when the SEIU sought to represent Lakeside Community Hospital employees in Clear Lake, California. The hospital filed multiple objections, including a "concern" it had regarding the local union's method of selecting vice presidents. In response, the NLRB issued a scolding: "Objections 1, 2, 3, 6, 13, 14, 16, 18, 19, 23, 24, and 28, appear to be frivolous and border on an abuse of the Board's processes. . . The Board frowns upon the filing by any party of multiple, obviously nonmeritorious objections" (emphasis added). The hospital not only continued its appeals but subsequently committed numerous ULPs, prompting two additional board orders and a case before the U.S. Court of Appeals, which was heard on September 13, 1993. As Lakeside has demonstrated, frowns are unlikely to convince determined employers to alter their union-avoidance practices.

The most commonly used remedy in cases of employer ULPs is a cease and desist order, which is to be posted in central locations on the company's property. Unfortunately, many employers simply ignore the order even if they post the decision as required. For example, Dayton Hudson Corporation has openly violated the law as a response to UAW organizing at its Detroit area stores. On August 9, 1991, an election at a store in Fairlane (a narrow loss for the UAW) was set aside by the NLRB because of numerous employer ULPs. The violations included threats, coercive interrogation, discipline of union activists, following employees into restrooms, videotaping workers while they spoke to union organizers, and monitoring phone calls. Hudson's was ordered to cease such behavior and to post notices to that effect. A new election was scheduled for October 30, 1992. While the notices were still posted, Hudson's repeated the same behavior-intimidation, harassment, threats, interrogation, and spying. The NLRB canceled the election and issued a complaint detailing more than one hundred separate violations. Hearings were held, and an ALJ decision was expected in late 1993.

In situations in which discharge is clearly tied to union activity, the NLRB will order reinstatement with back pay less interim earnings from other sources. The penalty is so modest, however, that it appears to be ineffective, as every case in the preceding section demonstrates. In fact, employers that discharge union supporters during organizing campaigns typically commit multiple other violations as well; consider, for example, the behavior of Rock-Tenn. 
The United Paperworkers International Union (UPIU) began organizing Rock-Tenn's Columbus, Indiana, facility in July 1989. The employer immediately started an aggressive antiunion campaign. Eight pro-union employees were discharged, union supporters were placed under surveillance, a nosolicitation, no-distribution rule was enforced, numerous employees were interrogated, and management threatened to close the plant and reduce benefits. The union lost a February 1, 1990, election 50-70. The NLRB issued complaints in October and December 1989 and in March 1990. The employer continued to harass and discriminate against union supporters, leading to more charges. Nonetheless, the union eventually achieved majority support in a second election on February 5, 1991. Over the next year the company engaged in hard bargaining while providing direct support to two employees who conducted a decertification campaign, and additional ULPs piled up. Finally, on May 25, 1993, an ALJ decision found Rock-Tenn guilty of virtually all ULPs plus violation of Weingarten rights and interfering with NLRB processes. The company appealed.

\section{UFCW v. Gress Poultry, Scranton, Pennsylvania}

The UFCW conducted an organizing campaign among 250 workers at Gress Poultry in 1986. In spite of the challenge of communicating in seven different languages to the largely immigrant workforce, the union was able to secure authorization cards from nearly 70 percent of the employees. An election was scheduled for December 23, 1986. The owners hired consultant Ray Blankenship to "run an anti-organizing campaign."

Blankenship held a series of three captive audience meetings for each of the three shifts, the first meetings in early December, the second ten days before the election, and the final meetings the day before the election. The theme at these meetings was straightforward: If the union won, the plant would be closed. Blankenship told the employees about one of his clients who had lost an election and padlocked the plant. To make sure that the message was understood by the multilingual audience, he held up a huge padlock for everyone to see. To drive the message home on election day, Blankenship held a picture of a lock and key and told employees that the employer had given him a padlock to lock the door when he closed the plant down. In addition to the threats, Blankenship took photographs of employees talking to union organizers and engaged in other acts designed to intimidate union supporters

After losing the election 114-71 with 38 challenged ballots, the union filed objections and charges of ULPs. Because Blankenship had actually delivered threats himself (most consultants stay in the background), he was charged jointly along with the employer. The case inched its way through the 
NLRB process with decisions for the union at every step. During the lengthy appeals process, support for the union eroded, and the UFCW gave up on its organizing objective. Along with the NLRB, however, the union continued to pursue the case against Blankenship.

On July 18, 1990, an ALJ found that Blankenship had committed five ULPs during the election. The ALJ issued a cease and desist order and a requirement that Blankenship post the order conspicuously in his Greenwood, Indiana, offices. Blankenship appealed to the NLRB. On March 31, 1992 , noting that Blankenship had a ten-year record of labor law violations in a series of cases for different employer clients, the NLRB upheld the ALJ decision. Blankenship appealed.

On July 15, 1993, the U.S. Court of Appeals enforced the NLRB order. In perhaps the ultimate statement attesting to the enforcement power of the NLRB, Blankenship submitted a certificate of posting indicating that the notice had been posted "on the seat of our employees' toilet." On September 8, 1993, the NLRB initiated civil contempt proceedings.

\section{First-Contract Problems}

As several cases we have already discussed make clear, winning a representation election does not necessarily secure union protection for workers. Utilizing the services of lawyers and consultants expert at frustrating the bargaining process, employers have been able to avoid such basic union protections as the grievance and arbitration system.

Although "surface bargaining" is considered a ULP by the NLRB, "hard bargaining" is tolerated. For example, the UMWA won an election at Shanefelter Industries in Uniontown, Pennsylvania, on April 26, 1991, by a vote of 22-6. The firm hired labor consultant Kelvin Berens from Omaha, Nebraska, to negotiate. As of October 1993, two and one-half years of monthly negotiations had resulted in no agreement on even basic issues. During bargaining the consultant displays a lackadaisical attitude by reading the newspaper while the union presents its proposals or engaging in idle banter about cattle ranching, skiing, or amusement parks to kill time and prolong the process. The union has repeatedly filed ULPs only to be told that "hard bargaining" is not a violation.

In January 1990, the International Brotherhood of Electrical Workers (IBEW) won an election in a fourteen-member unit against Coastal Electric Cooperative in Walterboro, South Carolina. The firm hired attorney Julian Gignilliat to negotiate. As of October 1993, agreement had not been reached on most key issues, including seniority, just cause, management rights, 
wages, and benefits. The company firmly opposes an arbitration clause, demanding that management be the last step in the grievance procedure. Gignilliat has stated that under the management proposal, if the union disagreed with the management's decision in the last step of the grievance process, it could strike "and I will replace every goddamn one of you." He also demands employment-at-will language. On September 18, 1992, an ALJ ruled for the union in a failure to bargain in good faith ULP case. The company appealed and the NLRB overturned the decision on June 30, 1993, reinstating a prior settlement agreement requiring the parties to meet and negotiate.

\section{BCTW v. Dawn Frozen Foods, Crown Point, Indiana}

In many cases. the company will stall negotiations for a year then support decertification efforts by, employees. The Bakery, Confectionery and Tobacco Workers' International Union (BCTW) won an election at Dawn Frozen Foods in Crown Point, Indiana, on March 28, 1991, by a 56-41 vote. Dawn hired attorney Robert Bellamy to negotiate. Negotiations were held monthly beginning in June.

There was no movement even on such simple issues as a union bulletin board. In February 1992 negotiations, Bellamy informed the union negotiating team that it would not be getting an "old ' 60 s Baker's contract" but a contract that reflected the "realities of the "90s." The "old" clauses that the company refused to consider included union security, dues checkoff, and plant visitation rights for union representatives. A decertification petition began to circulate in the spring with supervisor support. On June 10, 1992, an employee group filed for decertification, and a vote was set for July 8.

The company made what it labeled its final offer on June 21 . At this stage the union was not worried about the decertification vote because it had an internal organizing campaign in place, and seventy-plus workers were wearing union hats on the job every day. A federal mediator suggested that the union have the workers vote on the final offer, noting that management had told him that it could count hats and expected to lose the decertification election. The offer was voted down on June 28 , and the union requested a new bargaining session.

Coincidentally, on June 30, Robert Bellamy conducted an all-day seminar in Indianapolis, sponsored by the Indiana Chamber of Commerce, entitled "Remaining Union Free." In the final week before the decertification vote, the company ran an intense antiunion campaign with all of the standard ingredients: captive audience meetings, supervisors holding one-on-ones, the owner promising to give the workers everything the union had negotiated without union dues, and slides of the plant with a closed sign on the door. 
On July 7, Bellamy sent a letter to the union negotiator via certified mail responding to the request for a bargaining session to discuss the company's "final offer," which had been voted down:

That final offer remains final. . . .

-What final means is that Dawn is prepared to take a strike if its final offer is not acceptable....

-Final means you have gotten all there is to get - there is not one penny more-period.

-If a strike does occur, Crown Point will of course exercise its right to continue operations and hire replacements. ...

-If you do not believe me when I say that something is FINAL, go ask the

UAW in Cambellsville, Kentucky. After I gave a final offer, they went on strike over an open shop clause ... permanent replacements were hired, the union is now gone....

FINAL means FINAL.

Copies of the letter were hand delivered on the shop floor by supervisors to every employee. The next day, the BCTW lost the decertification election $51-48$.

\section{Conclusions and Policy Recommendations}

We believe that the cases collected by the Industrial Union Department lay bare the assumption of many academics and policy makers that blatant union busting is practiced only by a relatively small group of extremists in the management community. The underlying position of most employers is hostile to employee rights to organize and engage in concerted action. Given the widespread animus displayed toward unions and the current state of labor law, employer abuse of the right to organize is bounded only by the ingenuity of the lawyers and consultants who have made this field of practice their specialty.

We also believe that dramatic change in the law is needed to counteract the management union-busting convention. Based on the cases we have collected, a number of problem areas must be addressed if the right of workers to organize is to be protected.

1. Employer interference with workers' decision regarding unionization should be curtailed. Steps should be taken to limit management's ability to intimidate workers with threats, surveillance, and continuous supervisory pressure.

2. For employers who openly violate labor laws in order to defeat organizing campaigns, the costs of noncompliance must be increased. Particular 
attention should be given to proposals that would protect union supporters from discrimination, especially unjust dismissal.

3. Steps should be taken to speed up the NLRB process. Election delays allow management to exploit workers' fears and intimidate union supporters. Certification and bargaining delays deny workers the right to union representation and contract protection.

4. Restrictions should be placed on the role of consultants in unionavoidance campaigns. Penalties also should be considered for consultants and law firms associated with illegal union busting activities.

5. Steps should be taken to ensure that a decision by workers to unionize cannot be circumvented by employers that refuse to engage in good-faith bargaining.

Specific labor law reform proposals that address these concerns are spelled out in detail in the IUD.report Democracy on the Job: America's Path to a Just, High Skill, High Wage Economy. As summarized there, "The three prerequisites to rebuilding the union organizing process in this country are card majority recognition . . .; removal of employer interference from the certification process and greater union access to employees; and binding arbitration of the first contract" (AFL-CIO 1994).

The proposals offered by the IUD would place strict limits on employers' ability to thwart the right of workers to organize and join unions. They would also grant unions a reasonable opportunity to recruit new members in an atmosphere free of fear and intimidation. Finally, they would ensure that workers through their unions would have the opportunity to achieve contractual protection via meaningful collective bargaining. 